\title{
Research
}

\section{Resource Theft in Tropical Forest Communities: Implications for Non- timber Management, Livelihoods, and Conservation}

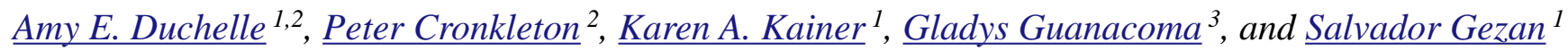

\begin{abstract}
Increased devolution of forest ownership and management rights to local control has the potential to promote both conservation and livelihood development in remote tropical regions. Such shifts in property rights, however, can generate conflicts, particularly when combined with rapidly increasing values of forest resources. We explored the phenomenon of Brazil nut (Bertholletia excelsa) theft in communities in Western Amazonia. Through interviews with 189 Brazil nut collectors in 12 communities in Bolivia and Brazil and participation in the 2006 and 2007 harvests, we quantified relative income derived from Brazil nuts, reported nut thefts, and nut collection and management practices. We found a much greater incidence of reported Brazil nut thefts in Pando, Bolivia than in the adjacent state of Acre, Brazil. Our analyses suggest that three factors may have affected nut thefts in the forest: (1) contrasts in the timing and process of formally recognizing property rights, (2) different historic settlement patterns, and (3) varying degrees of economic dependence on Brazil nuts. Threat of theft influenced Brazil nut harvest regimes, with potentially long-term implications for forest-based livelihoods, and management and conservation of Brazil nut-rich forests in Western Amazonia.
\end{abstract}

Key Words: Amazon; Bertholletia excelsa; Brazil nut; community forest management; land tenure; nontimber forest products; NTFPs

\section{INTRODUCTION}

Local communities may help determine tropical forest fates. Communities now own or manage onequarter of the world's tropical forests due to recent devolution of government-owned lands and formal recognition of customary rights (White and Martin 2002, Sunderlin et al. 2008). Such transfers of forest ownership and management rights to local control have the potential to promote both conservation and livelihood development in remote tropical regions (Sunderlin et al. 2005), where rural people often depend on forest resources for their economic wellbeing (Belcher et al. 2005). Devolution of property rights to community control, however, does not always promote forest conservation (Brown and Rosendo 2000, Gould 2006, Tacconi 2007a), but forest-dependent communities with secure rights may place greater emphasis on long-term forest management (McKean 2000, Colfer 2005, Sayer et al. 2008).
Such shifts in property rights, however, can generate forest-based conflicts, particularly when combined with rapidly increasing values of forest resources (de Jong et al. 2006). Also, rising resource prices may increase demand for property rights security (Demsetz 1967), and costs of enforcing those increasingly valuable rights may become prohibitive (Fitzpatrick 2006). Legitimate users may be excluded while others gain control (Meinzen-Dick and Mwangi 2008). Furthermore, as property rights shift and conflicts arise, the ability to enforce formal and informal rules that dictate resource use, long considered the basis of successful community-based resource management (Ostrom 1990, Agrawal 2001), may be jeopardized.

A simple, yet common manifestation of emergent forest-based conflicts is theft of forest resources, especially when demand for forest products is high and local access and exclusion rights are weakened (Koning et al. 2007). Illegal logging is a clear example of forest resource theft, and some of its 
primary causes are weak state governance, unclear property rights, and strong economic incentives for illegality (Tacconi 2007b). In ill-defined property regimes in the developing tropical world, resource theft could be either real or perceived. In real resource theft, criminals take advantage of tenure insecurity to take another person's property without their consent. In perceived resource theft, contradictory policies and confusion over the changing property rights systems create a situation where different actors feel entitled to the same resources. For instance, in the Eastern Brazilian Amazon, violent conflicts between landowners and squatters ensued when incompatible legal rights were granted to each of these groups on lands that were rapidly increasing in value (Schmink and Wood 1992, Alston et al. 2000). In this insecure context, timber thieves took advantage of the insecure tenure situation to pilfer valuable logs (Blate et al. 2002, Ros-Tonen et al. 2008). In northern Bolivia, overlapping land titles were granted to communities, timber concessions, and private estates, which resulted in conflicts, including perceived theft of high-value forest resources (Ruiz 2005).

These and other examples of forest-based conflicts suggest that much caution is needed during the increasingly common process of formalizing communities' often complex customary rights to land and resources. Communities manage natural resources both as common-pool and private assets (Ostrom 2003), with rights governed by local institutions often adapting over time (Gibson et al. 2000). Such complex property rights can be perceived as "webs of interest" made up of overriding, overlapping, complementary, or contested interests between multiple actors. Formalizing communal tenure may be akin to "cutting the web" (Meinzen-Dick and Mwangi 2008) if customary rules are overturned, and can result in unsustainable resource use if community members are unsure which rules apply (Fitzpatrick 2006). Furthermore, granting titles to land often ignores traditional tree tenure systems common in tropical forests (Fortmann and Bruce 1988), resulting in discrepancies between formal and customary rights. These arguments are not meant to diminish the importance of land titling, communal or otherwise, but rather highlight the need to not only address conflictive external claims to land and resources but also to recognize internal differences within communities (Agrawal and Gibson 1999) in the titling process, and to be alert to potential conflicts as they arise.
We explored the linkages between forest-based conflicts and property rights shifts through comparative research on the phenomenon of Brazil nut theft in neighboring Pando, Bolivia and Acre, Brazil in Western Amazonia. In this context, we define theft as the victim's perceived removal of their Brazil nuts without consent, independent of whether or not the perpetrator actually committed a wrongful act. Brazil nut (Bertholletia excelsa) is the most important non-timber forest product (NTFP) in this region, and while individual trees are considered key livelihood assets by forest dwellers in both countries, thefts of Brazil nuts in Bolivia had escalated and even generated violent responses at the onset of our study (El Deber 2005). We focus our comparison on these two adjacent areas because while they share a similar natural resource base and both have undergone recent property rights shifts to community control, there are marked differences in national forest policies and dependence on Brazil nuts by local communities. In this paper, we describe this contextual backdrop, and then present results of field studies on rural livelihoods and reported Brazil nuts thefts, and explore the causes of such thefts, along with their management implications. Specifically, we ask (1) To what extent do Brazil nut thefts occur in forest-dwelling communities in Pando and Acre? (2) What is the impact of these thefts on rural livelihoods? (3) Under what circumstances are thefts more likely to occur? and (4) How does threat of theft affect Brazil nut harvest and management? This comparative study addresses broader issues related to the role of property rights security and resource conflicts, livelihoods, and tropical forest management and conservation by rural communities.

\section{Study region}

In the approximately $220,000 \mathrm{~km}^{2}$ border region of Acre, Brazil and Pando, Bolivia, many nonindigenous extractive communities - whose principal livelihood activity is collection of forest products - share the landscape with indigenous groups and more recently settled farmers, cattle ranchers, and loggers. The region is characterized by lowland wet tropical forest vegetation, but settlement histories, patterns of deforestation, public policy, and socioeconomic development vary considerably from one country to the next ( $\underline{\mathrm{w}}$ ww.map-amazonia.net). Construction of the Interoceanic Highway, an extension of the Brazilian BR-317 into Peru, is changing conditions in this formerly remote region by providing regional 
access to Pacific ports (Fig. 1). In Acre, forest conversion has been rapid, extensive, and largely driven by establishment of cattle ranches (Souza et al. 2006). In Pando, in contrast, deforestation has been minimal, with most land conversion occurring near population centers and along the Brazilian border (Marsik et al. in press).

\section{Role of Brazil nut in forest conservation and livelihood development}

Because of its combined ecological and economic characteristics, Brazil nut has the potential to promote forest conservation while contributing to the livelihoods of rural communities. Brazil nuts are collected almost solely from mature upland forests. At maturity, these trees are giants; they emerge above the forest canopy, attain up to $3 \mathrm{~m}$ in diameter, and live for centuries. Because of its massive size and high relative densities, this species provides important ecological structural and functional roles at the local and landscape scale (Zuidema 2003). Its large, woody fruits fall to the ground during the wet season and retain the approximately 25 seeds (hereafter referred to as nuts) inside the hard pericarp. The scatterhoarding agouti (Dasyprocta spp.), a rodent, is one of the few animals that can gnaw through the hard fruits, and it plays an instrumental role in seed dispersal and burial. People access the nuts by gathering the heavy fruits in large piles, breaking them open with a machete, and then gathering the released nuts in large sacks for transport out of the forest. Although Peres et al. (2003) suggested that decades of commercial harvesting may leave insufficient juvenile recruitment to ensure future generations, populations in Western Amazonia appear to be viable over the medium-term under a range of harvest intensities (Zuidema and Boot 2002, Wadt et al. 2008). Harvested nuts can be counted on as a seasonal contribution to local livelihoods because there is little variability in fruit production at the population level across years (Kainer et al. 2007). The nuts fetch relatively high prices on local, national, and international markets, particularly since 2003, largely due to crop failures of other economically competitive nuts. Western Amazonia is the current center of the Brazil nut economy, employing tens of thousands of families during the primary collection season (January-March; Bojanic 2001). Because of Brazil nut's regional economic importance, Brazilian, Bolivian, and Peruvian legislation prohibit felling the trees.

\section{History of forest extraction and devolution of community rights in Western Amazonia}

The history of colonization and settlement by nonindigenous extractive populations in Acre and Pando began in the late $19^{\text {th }}$ century during the first boom in natural rubber (Hevea brasiliensis), and has since been shaped by distinct changes in policy and market demands (Table 1). Immigration to rubber estates in the Western Amazon, into Pando and what is now Acre (which at the time was officially Bolivian territory; Barham and Coomes 1996), exploded after the 1870s. When Malaysian plantation rubber entered the international market in 1912, rubber prices fell, and Brazilian and Bolivian rubber tappers began to diversify their livelihood strategies to include Brazil nuts and agriculture as seasonal, complementary activities (Fifer 1970, Barham and Coomes 1996, Stoian 2000). Some value-added processing of Brazil nuts also was introduced. Although a second, smaller rubber boom ensued when Asian plantation rubber was monopolized by the Japanese in World War II (Sobrinho 1992), it was short-lived, and slowly Brazil nuts began to play a more prominent role in regional livelihoods. By the 1950s, nut exports surpassed those of rubber, and the first "official boom" of the Brazil nut sector occurred in the 1990s (Stoian 2000).

Although the rubber industry did not promote longterm economic development in Amazonia (Weinstein 1983, Barham and Coomes 1996), it was critical in setting the stage for current Brazil nut harvester settlement patterns. In Acre and Pando, communities were formed by families of rubber tappers who continued to live on rubber estates even after rubber prices dropped. In Acre, these families maintained their traditional isolated distributions throughout the forest even as the lands beneath them were either sold off or abandoned by the traditional rubber estate owners to cattle ranchers (Sobrinho 1992). In contrast, families in Pando tended to congregate as rubber lost value, while owners of these forested estates maintained their privileged position by dominating large-scale production of Brazil nuts (Stoian 2000). This communal settlement pattern was reinforced as municipal governments provided infrastructure and services to communities in response to Bolivia's 1994 Popular Participation Law. Formation of concentrated communities in Pando meant that forest landholdings were occupied only during portions of the Brazil nut harvest season (Cronkleton et al. 2007; Fig. 2). During the 1990s, key policy changes 
Fig. 1. Map of Madre de Dios, Peru, Acre, Brazil and Pando, Bolivia (MAP region) with main roads indicated (including new stretch of paved Interoceanic Highway from Assis to Puerto Maldonado), along with communities sampled in Acre and Pando.

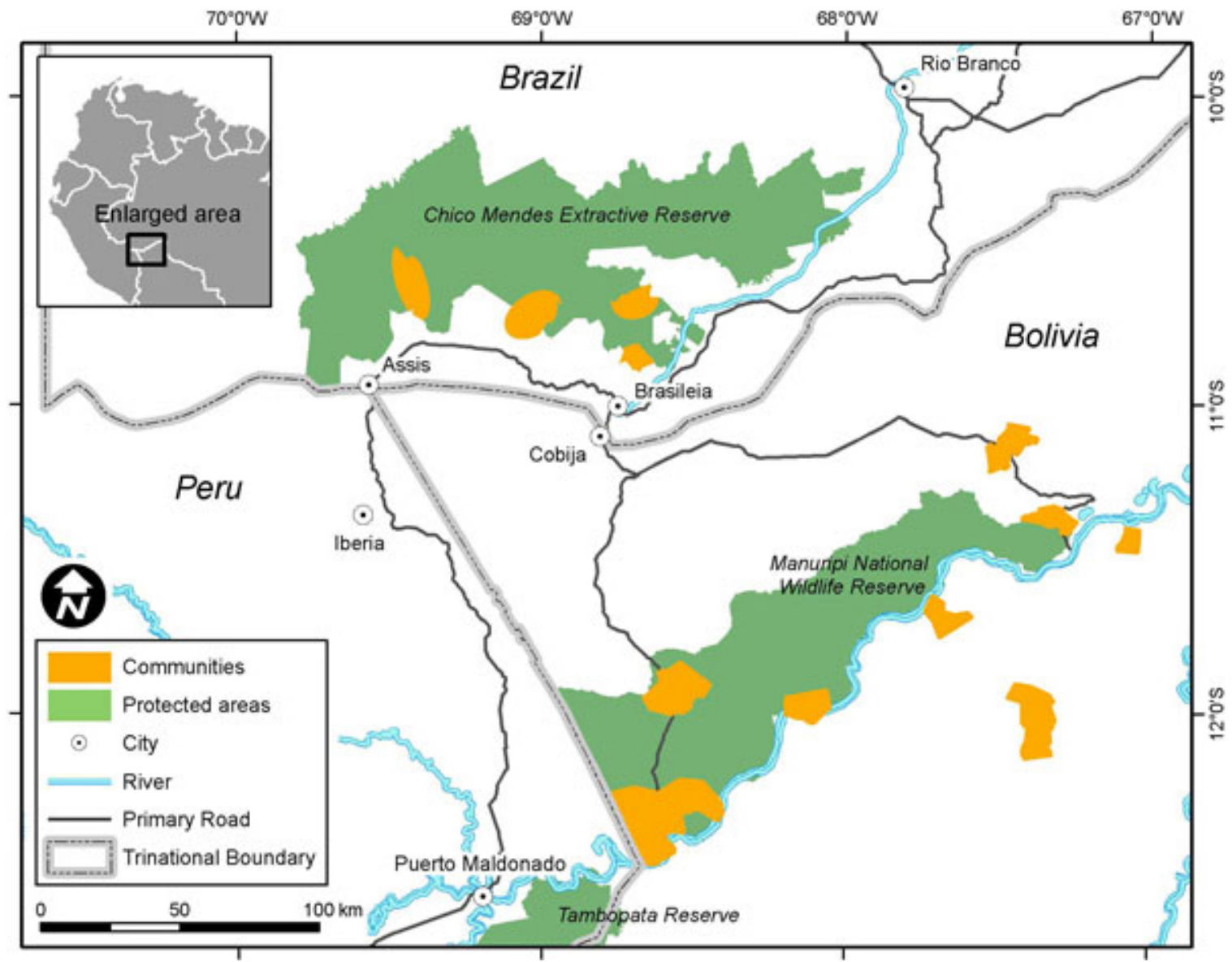

formally recognized property rights of communities in these two countries through the establishment of Extractive Reserves in Brazil, and passage of a new Forestry Law and Agrarian Reform Law in Bolivia. The origin of these policy changes and how they were implemented in Acre and Pando have important consequences for extractive activities in the region today.

Extractive Reserves, championed as a viable and sustainable alternative to widespread deforestation in the Amazon (Allegretti 1989, 1990), are distinguished from other Amazonian protected areas in that they were created "not despite but because of people" (Ehringhaus 2006). Indeed, the first reserves were created in Acre, where rubber tappers intent on securing land tenure, used international environmental concerns about the Amazon to their advantage, portraying themselves as forest stewards (Schmink and Wood 1992). In this property rights model, the Brazilian government owns the land, and usufruct rights are guaranteed to resident communities engaged in traditional livelihoods based largely on collection of NTFPs; they also must maintain at least $90 \%$ of their landholdings in forest cover (Fearnside 2003). In the one million hectare Chico Mendes Extractive Reserve in Acre, which was created in 1990 from 42 former rubber estates, communities are organized into associations with decision-making power at the Reserve level, and households spread throughout the mostly forested landscape are 
Table 1. Important historical events and relevant forest policy changes in Acre, Brazil and Pando, Bolivia. These events continue to affect property rights, the diversity of forest products currently exploited, and ultimately, the frequency of Brazil nut thefts.

Acre, Brazil

Pando, Bolivia

1876-1910: Rubber boom (migration to region)

1903: Acre ceded from Bolivia to Brazil (Fifer 1970)

1870s: Nicolas Suarez founds Suarez Hermanos rubber company (Fifer 1970)

1910-1940: Decline in rubber economy; Diversification of production to include Brazil nut harvesting and agriculture

1912: Malaysian plantation rubber pierces global market (Weinstein 1983)

1933: Brazil nut processing plant inaugurated in Xapurí, Acre, exporting canned nuts to the U.S. (Wadt et al. 2008)

1940-1945: Renewed demand for rubber

1942: Brazil-U.S. Washington Accords to recruit Brazilian rubber tappers to Amazon (Sobrinho 1992)

Suarez and Hermanos control $80 \%$ of rubber production in Brazil-Bolivia border (Fifer 1970)

\section{0-1990s: Brazil nuts replace rubber as main forest product}

1986: Removal of Brazilian subsidy for rubber that had been extended to Bolivian producers

1990s: New policies for extractive communities

granted individual parcels (Vadjunec et al. 2009) that can range from 300 to more than 1000 ha. Even though Brazil nut has replaced rubber as the most important forest product (Wallace 2004), the unique tree tenure legacy from the rubber era is still honored, and reserve residents define individual property holdings by the number and distribution of rubber trails through the forest (Ankersen and Barnes 2005). Proprietors of Brazil nut trees that fall within individual parcels are locally well defined.

In Bolivia, the Forestry Law and the Agrarian Reform Law, both passed in 1996, affected forestdwelling communities in Pando. Although the Forestry Law focused on timber production, it had several important implications for community management of NTFPs. In particular, establishment of an area-based land tax discouraged timber companies from maintaining large landholdings, making more forested land available to communities (Contreras and Vargas 2001). Forest access was democratized by recognition of indigenous subsistence rights and creation of several avenues through which communities could participate in logging - an activity previously prohibited (Ruiz 2005). In the early 2000s, despite ongoing struggles between large landholders and communities to control forest resources and lands, modifications of the Agrarian Reform Law in northern Bolivia gave forest-dwelling communities legal rights to 500 ha per family, with the total area of the communal title determined by the official number of resident families (Ruiz 2005, Cronkleton and Pacheco 2010). As of 2008, 139 of the 163 communities in Pando had received titles based on the 500-ha decree (Cronkleton and Pacheco 2010), including the nine communities located within the Manuripi National Wildlife Reserve, a 750,000-ha protected area for sustainable use that is a mosaic of private estates and communities (Kühne 2004). Despite these successes in community titling, there 
Fig. 2. Google Earth images from July 2007 of forest-based settlements in Acre, Brazil (left) and Pando, Bolivia (right). Note contrast between dispersed pattern of household clearings in Acre's Chico Mendes Extractive Reserve (households circled) and a concentrated community settlement in Pando (community circled).
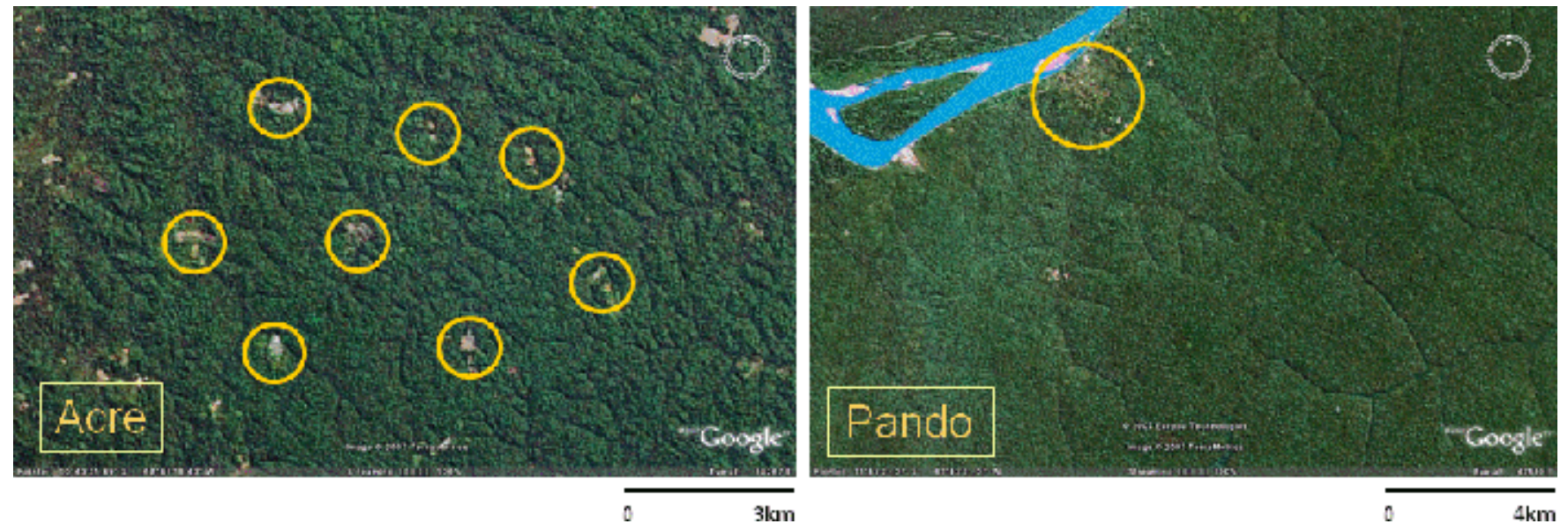

was little acknowledgement of customary resource rights or consultation with the communities themselves in the process. For instance, proprietorship in these communities had been increasingly defined by the natural distribution of Brazil nut trees throughout the forest such that even in cases where official community institutions are weak, access and exclusionary rights to Brazil nut trees and trails are often clearly defined, especially in well-established communities (Cronkleton et al. 2010). The 500-ha decree, however, did not take rights to Brazil nut trees into account, and erroneous expectations emerged that the government would rearrange internal resource access so that everyone could have a 500-ha plot, undercutting the traditional tree tenure system. In many cases, communal titles were incongruent with the natural external boundaries that communities had used for seasonal forest use, such as rivers, and maps presented to communities lacked geographic features that were familiar to residents, causing boundary problems to go unnoticed (Cronkleton et al. 2010). Also, the calculation of total community area, based on 500 ha per person, was often based on erroneous community lists. Such errors in the formalization of communal rights resulted in a climate of property rights insecurity and conflicts within and between newly titled communities in Pando (Cronkleton et al. 2010).

\section{METHODS}

\section{Field evaluation of rural livelihoods, Brazil nut thefts, and management practices}

We evaluated rural livelihoods, reported Brazil nut thefts, and nut management practices in eight communities in Pando and four in Acre through interviews with 189 households (131 in Pando, 58 in Acre) and through participation in the 2006 and 2007 Brazil nut harvests. In Pando, communities were chosen to represent differences in market access (river vs. road) and distance to major market centers, and were located both within (4) and outside (4) of the Manuripi National Wildlife Reserve. In Acre, the four communities sampled differed in their proximity to rivers or roads and their distance to central markets, but all were in the Chico Mendes Extractive Reserve (Fig. 1). Large distances between households in Acre extended field survey time, precluding an equal sample size between the two countries. In communities with < 30 families, all available families participated in the study; otherwise, representative samples were chosen at random from lists of total households that were generated through consultation with community leaders. 
To evaluate rural livelihoods, we conducted two annual village and household-level socioeconomic and environmental questionnaires and four quarterly household questionnaires from June 2006 through August 2007, as part of the Center for International Forestry Research Poverty and Environment Network (CIFOR PEN; http://www.c ifor.cgiar.org/pen/ ref/home/index.htm). We quantified general livelihood variables through the village and household-level annual surveys and used quarterly surveys over a 12-month period to measure subsistence and cash income derived from forests and other on- and off-farm activities, including agriculture, livestock, wage labor, and other sources of external economic support. We used this detailed evaluation to calculate total household income and analyze the relative contribution of Brazil nut to household livelihoods in Pando and Acre.

Since it was impossible to attain observational information on Brazil nut thefts, we relied on informant accounts of where and how many nuts were stolen from them by whom, and what, if anything, was done to resolve the matter during the 2006 and 2007 nut harvests. Producers were able to estimate the quantity of Brazil nuts stolen based on the number of opened fruit shells left on the ground when nuts were collected. To evaluate Brazil nut harvest and management practices, we categorized them by (1) initial harvest date, (2) harvest method and overall harvest duration, and (3) management practices designed to (a) promote regeneration (e.g., protection of seedlings from fire), (b) enhance fruit yield (e.g., vine cutting), and (c) meet certification standards (e.g., nut drying). These management variables were chosen from local literature on best management practices (e.g., Wadt et al. 2005) and the first author's participation in the 2006 Brazil nut harvest. We also recorded apparent lack of management, as well as intentional or unintentional practices that may adversely affect individual trees.

\section{Data analysis}

To understand basic quantitative differences between Brazil nut-producing households in Pando and Acre, we generated descriptive statistics for (1) household characteristics, access to government services, land tenure, distance to markets and forest resources, and income; (2) incidence, type, and financial costs of nut thefts; and (3) nut harvest and management practices. We then performed several analyses to evaluate variables that predicted, or were predicted by, presence or absence of theft. For these analyses, the data set included measurements from 171 of the total 189 households (125 in Pando and 51 in Acre) that had robust records over two consecutive years (2006 and 2007). Therefore, this data set corresponded to repeated measures with two time points.

In the first analytical stage, we searched for relationships between reported incidence of theft and possible predictor variables for both countries using two years of combined data. For discrete variables, such as road or river access and perceptions of property rights security, Chi-square tests were used. For continuous variables, such as distance to market, distance from households to individual nut stands, and income derived from Brazil nuts, logistic regressions were fitted. This process guided our selection of potentially relevant variables $(p \leq 0.10)$ to be included in a more complete, single model to analyze theft. For this, we developed a stepwise generalized linear model based on a binomial distribution and a logit link where model response was presence or absence of theft. Autocorrelation of the errors was evaluated because these data contained repeated measures, but was not statistically significant and therefore was dropped from the analysis. Models were fitted using the software SPSS Statistics GradPack 17.0 (2008).

In the second analytical stage, we searched for relationships between reported incidence of theft and possible harvest and management response variables across four subgroups comprising country $\mathrm{x}$ year combinations. Again, for discrete variables, such as Brazil nut harvest method and specific management practices, Chi-square tests were used. For continuous explanatory variables, such as length of harvest and amount of nuts collected, we used ANOVA. Again, this process guided our selection of potentially relevant variables $(p \leq 0.10)$ to be included in a model that combined data from all countries and years to investigate presence or absence of theft as a predictor of harvest and management.

We modeled each selected response variable considering a year and group factor, together with interactions. Year and group were assumed to be fixed effects. Group factor was a categorical 
variable formed by three classes: (1) observations with theft in Pando, (2) observations without theft in Pando, and (3) observations without theft in Acre. Thefts in Acre were so rare (only 11 reported over a 2-year period) that a fourth potential class (i.e., observations with theft in Acre) was not statistically viable for model inclusion. In this analysis, the presence of autocorrelation among observations was relevant and therefore was incorporated into the model. The continuous and discrete responses were fitted by using a linear mixed model and a generalized linear mixed model, respectively, as implemented in GenStat v.11 (Payne et al. 2007).

\section{RESULTS}

\section{Comparative livelihoods data}

Overall, while households in Pando and Acre were similar in terms of size, land area, and time lived in the community, they differed significantly in distance to markets and forest resources (Table 2). While more than half of households sampled in both places had access to roads from village centers, communities in Pando were located much farther from market centers $(p<0.001)$. Also, in Pando, distance from households to individual Brazil nut stands was greater than in Acre $(p<0.001)$. This difference reflects the concentrated nature of communities in Pando, which contrasts with the more diffuse spread of Acrean forest-based households. Households sampled in Pando had more years of schooling $(p<0.001)$ and better access to health services $(p<0.001)$, whereas households in Acre had better access to piped water ( $p<0.001$; Table 2). There was also some evidence that households in Pando had better access to electricity ( $p=0.06$; Table 2$)$.

While total income was similar, income derived from forests and Brazil nuts was greater in Pando than in Acre (Table 2). Forest income made up 63\% of the total share in Pando versus $42 \%$ in Acre (Table 2). Similarly, Brazil nut income, as a subset of forest-based income, contributed significantly more to household livelihoods in Pando than in Acre. In Pando, Brazil nuts alone contributed $43 \%$ of the total income share versus just $14 \%$ in Acre (Table 2). Reported mean (and SD) volume of nuts harvested per household in Pando was $6187( \pm 7590) \mathrm{kg}$ in $2006(n=125)$ and $4508( \pm 3856) \mathrm{kg}$ in $2007(n=$ 115). In Acre, it was much less at $1807( \pm 1844) \mathrm{kg}$ in 2006 and $1812( \pm 1737) \mathrm{kg}$ in 2007.

\section{Frequency, causes, and effects of reported Brazil nut thefts}

Theft of Brazil nuts was reportedly much more frequent in Pando than in Acre $(p<0.001)$. In Pando, approximately half of all households reported nut thefts: $61 \%$ of 125 households in 2006, and $45 \%$ of 115 in 2007 . In Acre, only $14 \%$ of 51 households and $9 \%$ of 42 households reported nut thefts in 2006 and 2007 harvests, respectively. In both countries, most thefts were of nuts from the forest floor $(81 \%$ in Pando and $91 \%$ in Acre), rather than of sacks or storage areas, suggesting that some reported thefts were due to confusion over customary tree tenure rather than outright stealing.

Nut thieves were reportedly members of the same community, members of neighboring communities, or, at least in Pando, migrant workers employed by private estates during the harvest season (Fig. 3). Most of these workers arrived in large boats from the downstream city of Riberalta where they were employed in nut shelling and drying during the rest of the year. In Pando, half of all thefts were reputedly committed by members of the same community (45\% in 2006, 52\% in 2007). In Acre, all 11 cases of thefts were reportedly perpetrated by other harvesters from the same and neighboring communities - migrant workers hired for nut collection were nonexistent.

In Pando, reported volumes of Brazil nut thefts were substantial (Table 3), comprising 22\% of the total combined harvest in 2006 and 2007. This meant annual losses of US\$719 (range \$11-\$5750), representing $13 \%$ of the US\$5394 mean $( \pm \$ 4764$ SD) annual combined subsistence and market income per household in Pando. In labor terms, the estimated mean of $1498 \mathrm{~kg}$ of nuts stolen per year represents the loss of approximately 22 days of household labor, given that $69 \mathrm{~kg}$ of nuts is equivalent to one day's labor. In Acre, with minimal reported thefts and proportionately less income from Brazil nuts, financial consequences of thefts were far less important.

Results of the Generalized Linear Model showed that distance variables were the most important quantitative determinants of Brazil nut theft (Table $4)$. Households with nut stands farther away from the home tended to experience more thefts $(p<$ 0.001 ), as did households in communities further from markets $(p=0.001)$. There may have been a slight tendency ( $p=0.136)$ for households with 
Table 2. Descriptive statistics of household characteristics, access to government services, distance variables, and household income sources in Pando and Acre.

\begin{tabular}{|c|c|c|c|c|c|}
\hline \multirow[b]{2}{*}{ Variable } & \multicolumn{2}{|c|}{ Pando, Bolivia } & \multicolumn{2}{|c|}{ Acre, Brazil } & \multirow[b]{2}{*}{$p$ value } \\
\hline & $N$ & Mean (SD) & $N$ & Mean (SD) & \\
\hline \multicolumn{6}{|l|}{ Household characteristics } \\
\hline Size (\# people) & 125 & $6.0(2.8)$ & 51 & $5.4(2.9)$ & 0.159 \\
\hline Land area (ha) & 125 & $587(470)$ & 51 & 638 (499) & 0.519 \\
\hline Head of household born in community & 125 & $0.20(0.40)$ & 51 & $0.20(0.40)$ & 0.670 \\
\hline Time lived in community (yrs) & 125 & $17(15)$ & 51 & $15(11)$ & 0.238 \\
\hline Schooling (cumulative yrs) & 125 & $21.4(13.7)$ & 51 & $12.3(7.7)$ & $<0.001$ \\
\hline \multicolumn{6}{|l|}{ Access to government services } \\
\hline Electricity & 125 & $0.38(0.49)$ & 51 & $0.24(0.43)$ & 0.060 \\
\hline Piped water & 125 & $0(0)$ & 51 & $0.18(0.39)$ & $<0.001$ \\
\hline Health services & 125 & $0.30(0.46)$ & 51 & $0(0)$ & $<0.001$ \\
\hline \multicolumn{6}{|l|}{ Distance } \\
\hline Road access & 125 & $0.65(0.48)$ & 51 & $0.78(0.42)$ & 0.078 \\
\hline Distance to market from village center $\dagger(\mathrm{hrs})$ & 125 & $9.5(7.1)$ & 51 & $2.4(1.4)$ & $<0.001$ \\
\hline $\begin{array}{l}\text { Distance to Brazil nut stand from household } \\
\text { (min) }\end{array}$ & 124 & $81(93)$ & 51 & $6(4)$ & $<0.001$ \\
\hline \multicolumn{6}{|l|}{ Household income $2006-2007 \ddagger$} \\
\hline Total income (USD) & 107 & 5394 (4764); 100\% & 47 & 5460 (2759); $100 \%$ & 0.930 \\
\hline Forest-based income (USD) & 107 & 3423 (3604); 63\% & 47 & 2319 (1295); $42 \%$ & 0.043 \\
\hline Brazil nut income (USD) & 107 & 2304 (1837); $43 \%$ & 47 & 765 (973); 14\% & $<0.001$ \\
\hline
\end{tabular}

$\dagger$ In the dispersed settlement in the Chico Mendes Extractive Reserve in Acre, village center was defined as the association hub where community meetings took place.

$\ddagger$ These values include absolute income and percent of total household income. 
Fig. 3. Suspected perpetrators of Brazil nut thefts in 2006 and 2007 (\% of total incidents). Sample includes only those households that reportedly experienced thefts.
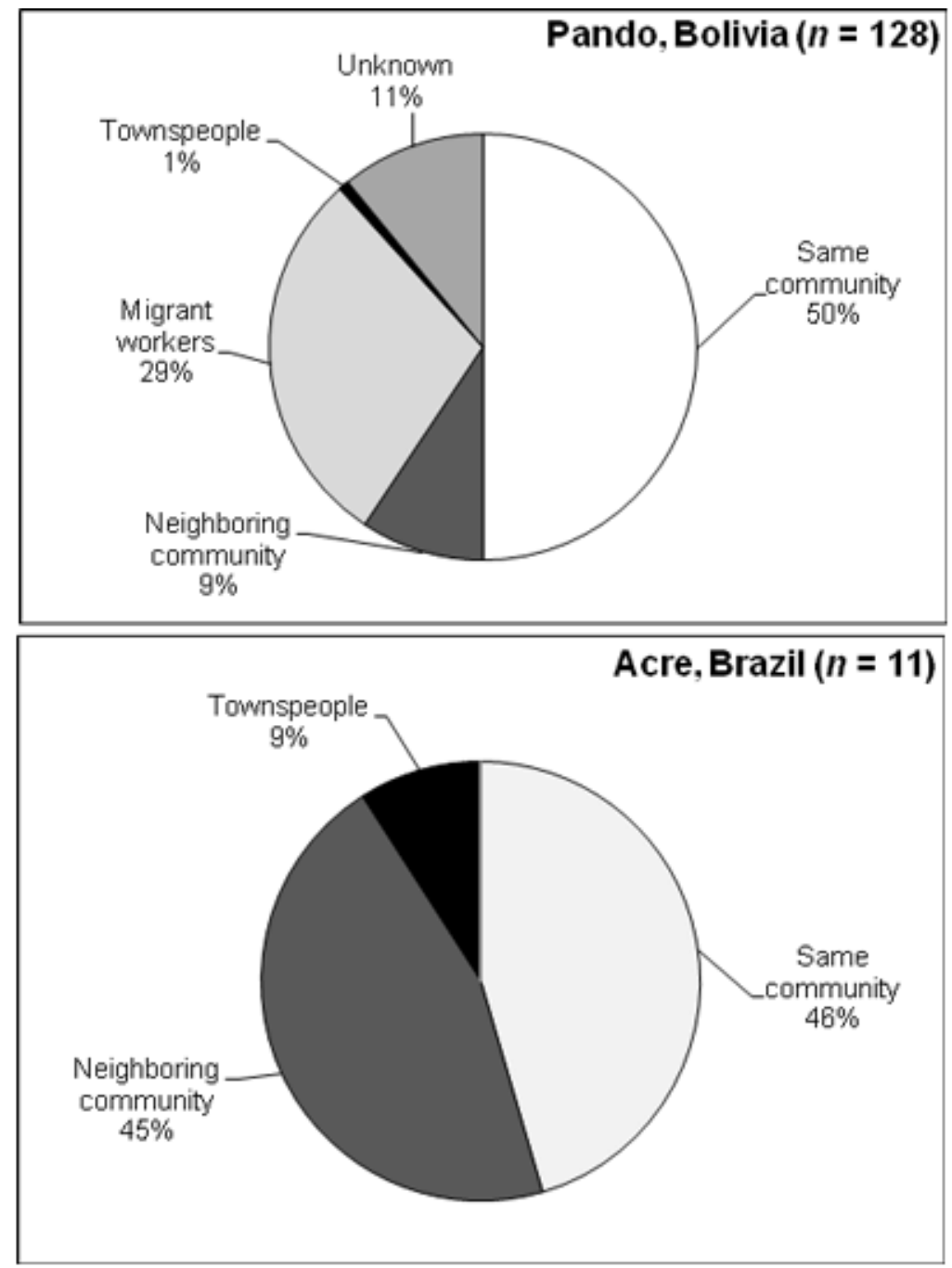

greater income derived from Brazil nuts to be more vulnerable to theft, but neither household land area $(p=0.277)$ nor road versus river access $(p=0.534)$ were implicated.

Brazil nut harvest regimes were distinctly different in Pando and Acre. Harvest began much earlier and lasted much longer in Pando than in Acre (Fig. 4). The year $\mathrm{x}$ group analysis used to compare harvest and management patterns across countries and incidence of theft showed a significant difference between both harvest start date and duration of harvest in Pando versus Acre $(p<0.001)$, as well as quantity of nuts collected $(p=0.007)$. No countrylevel differences were detected within Bolivia, however, when comparing households that directly experienced theft with those that did not (Table 5).

Harvesters reported the use of three different collection methods: (1) collect as many fruits as possible in one day, breaking them open for immediate transport of nuts from the forest; (2) collect and group fruits from one trail into piles, leaving them in the forest for one to several days 
Table 3. Total volume and value of Brazil nuts reported stolen in 2006 and 2007 combined. Values in USD based on mean price/year paid to collectors by middlemen during the 2006 (\$0.46/kg in Pando; $\$ 0.40 / \mathrm{kg}$ in Acre) and 2007 (\$0.50/kg in Pando; $\$ 0.44 / \mathrm{kg}$ in Acre) harvests.

\begin{tabular}{lccccccc}
\hline \hline & \multicolumn{3}{c}{ Pando, Bolivia } & & \multicolumn{3}{c}{ Acre, Brazil } \\
\cline { 2 - 3 } \cline { 6 - 7 } Variable & $N$ & Mean (SD) & Range & & $N$ & Mean (SD) & Range \\
\hline Amount stolen (kg) & 104 & $1498(1810)$ & $23-11,500$ & 9 & $216(158)$ & $58-483$ \\
Percent of harvest (\%) & 104 & $22(19)$ & $0.82-100$ & 9 & $10(7)$ & $0.5-23$ \\
Value (USD) & 104 & $719(875)$ & $11-5750$ & 9 & $90(67)$ & $23-202$ \\
\hline
\end{tabular}

and then returning to open them; or (3) over the course of several days or weeks, collect and group all fruits from one's landholding and then return to open them later. Notably, $96 \%$ of Bolivian collectors, whether they experienced theft or not, gathered, opened, and transported nuts in the same day, whereas Brazilian producers engaged in a variety of collection methods (Fig. 5). Most Bolivian producers indicated threat of theft as the main reason they transported nuts out of the forest early in the season and as quickly as possible.

With the exception of the collection practices described above, no correlations were found between incidence of theft and implementation of any other specific management practices (e.g., protecting seedlings from fire, vine cutting) in Pando and Acre. This finding suggests that despite threat of theft, people felt enough proprietorship over their Brazil nut stands to manage for future fruit production and tree growth.

Victims of nut theft rarely received compensation for their losses. In Pando, only $17 \%$ of the 76 cases of theft in 2006 and $6 \%$ of 52 cases in 2007 came to some resolution. Of the 11 theft cases reported in Brazil in 2006 and 2007 combined, only two were resolved. Resolution usually involved discussions between the two conflicting parties, with full or partial success in the return of stolen nuts. In some cases, community officials mediated the disputes. In one extreme case in Pando, where workers of a former private estate owner stole an estimated 4600 $\mathrm{kg}$ from a newly titled community, a municipal official helped resolve the issue. The officer attended a community meeting, exercised his authority, and ensured that the monetary equivalent of the stolen Brazil nuts was returned and redistributed to the whole community.

\section{DISCUSSION}

We found a much greater incidence of reported Brazil nut thefts in Pando, Bolivia than in the adjacent state of Acre, Brazil. Although we were unable to study the direct causes, our analyses suggest three factors may have affected nut thefts in the forest: (1) contrasts in the timing and process of formally recognizing property rights, (2) different historic settlement patterns, and (3) varying degrees of economic dependence on Brazil nuts.

\section{Comparative timing and process of property rights formalization}

Whereas forest residents in Acre and Pando share very similar extractive histories, when and how property rights were devolved to them differed, and while speculative, seemed to impact reported resource thefts. "Demand from below" motivated by social movements and local governments (Larson et al. 2007) is considered an important component of effective decentralization measures (Larson and Soto 2008). In Acre, the Extractive Reserve model was a response to a bottom-up, successful political struggle by rubber tappers to secure property rights. As a result, customary tenure 
Table 4. Results of a stepwise logistic regression used to identify the most important measured variables that explained incidence of Brazil nut thefts in 2006 and 2007 in Pando and Acre $(n=235)$. No significant interactions between variables were detected.

\begin{tabular}{lcccc}
\hline \hline Variable & Estimate & Wald & $P$ value & Odds Ratio \\
\hline Distance to Brazil nut stand from household (min) & 0.001 & 13.051 & $<0.001$ & 1.001 \\
Distance to market from village center (hrs) & 0.023 & 11.891 & 0.001 & 0.136 \\
Income from Brazil nuts (USD) & 0.00002 & 2.224 & 0.277 & 1.023 \\
Total landholding area (ha) & 0.00006 & 1.183 & 0.000 \\
Road access & -0.057 & 0.387 & 0.534 \\
\hline
\end{tabular}

of dispersed household settlements throughout the forest was recognized when land rights were formally devolved. The inner boundaries of individual landholdings continued to be as well defined among extractivists as they were during the rubber era. The outer boundary of the Chico Mendes Extractive Reserve was relatively undisputed when the reserve was created because claims contested by large landholders were mostly settled by the federal government and were heavily regulated by the Brazilian environmental protection agency (C.V. Gomes, personal communication). At the time of our field research (2005-2007), residents of the Reserve had more than 15 years to adjust to the property rights supported by reserve creation in 1990. Reserve co-management with the Brazilian government engenders continuous dialogue related to extractivist rights to land and resources.

In contrast, communities in Pando only recently emerged from a struggle with private estate owners to have their customary property rights recognized by the government. Additionally, this formalization of rights was handed down from the state to mostly well-established communities that had managed their Brazil nut groves communally for many years via internal norms and rules. Our data showed the greatest proportion of thefts in Pando was presumed to be by members of the same community. Throughout Pando, such intra-community conflicts were commonly associated with the 500-ha decree, which created local confusion that the government would rearrange internal resource access so that everyone could have a 500-ha plot. Additionally, there was often abrupt incorporation of landless people into already established communities to facilitate access to land and municipal services; these newcomers were probably unaware of customary management systems. In sum, the more recent, top-down process of formalizing communal tenure in Pando may have resulted in comparatively greater property rights insecurity and increased incidence of thefts. This type of confusion over internal property rights along with high economic incentives for uncontrolled collection (Tacconi 2007b) contrasts with other studies on surreptitious forestry activities, such as illegal logging, which are often the result of operations by sophisticated clandestine organizations (Honey-Roses 2009).

\section{Influence of settlement patterns and resource dependence on theft}

The distinct spatial distribution of forest-dwelling communities in Acre versus Pando also contributed to observed differences in reported Brazil nut thefts. This finding was supported by our quantitative result that distance of household to Brazil nut stand was the most important predictor of theft. In Acre, through creation of the Chico Mendes Extractive Reserve, households maintained their traditional dispersed spatial distribution throughout the forest, allowing them close access to and daily interactions with their forested landholdings (Allegretti 1990). These nut collectors walk their properties to hunt, 
Fig. 4. Modal start and end dates of Brazil nut harvest, and harvest duration, in Pando and Acre in 2006 and 2007. Primary harvest period (dark gray) is when most producers report the beginning and end of harvest. Extended harvest period (light gray) is indicated by earliest and latest harvest dates.

Pando, Bolivia

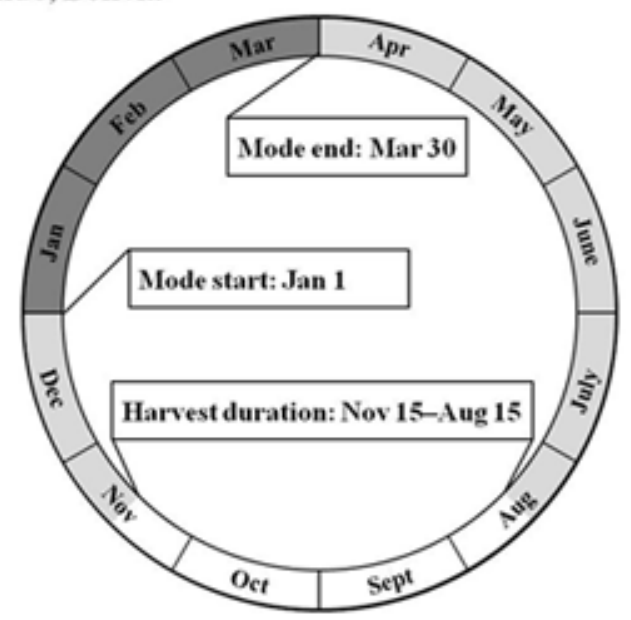

Primary Brazil nut harvest period

Maximum extent of Brazil nut harvest

No Brazil nut harvest
Acre, Brazil

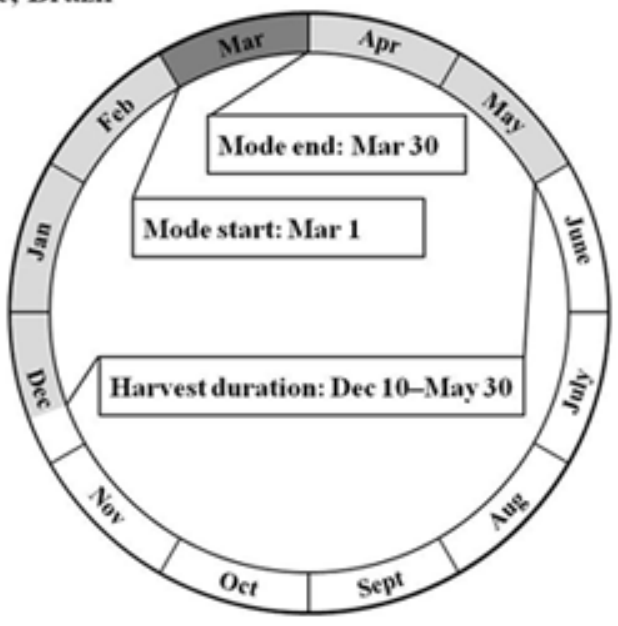

tap rubber, work their agricultural fields, and travel to neighboring households. They constantly monitor their land and resources, dealing with disputes quickly. In Pando, in contrast, the 1994 Popular Participation Law encouraged the concentration of rural families in settlements to access municipal government education, health, water, and electricity services. This policy had the unintended result of removing families from dayto-day monitoring of their forest resources. Our data showed that households with Brazil nut harvest areas far from village centers experienced more nut thefts, likely by members of neighboring communities and migrant workers. While Bolivian harvesters would relocate to remote harvest areas for portions of the nut harvest, these stays were often intermittent so as to maintain connections with the village center for supplies. Disputes over resources might only manifest themselves during the Brazil nut harvest, which contrasts markedly with the yearround patrols of Acrean extractivists of their forested landholdings. That said, the higher education levels and better access to health services among nut producers in Pando, along with some evidence of better access to electricity, showed that while Brazilian producers may be better able to monitor their forest landholdings, their access to services (with the exception of piped water) is indeed inferior when compared with their Bolivian counterparts. Such a trade-off could have negative implications for rural development in Acre.

In addition to differences in spatial settlement patterns, higher relative dependence on Brazil nuts in Pando versus Acre (Table 2) may also have influenced theft of this high-value resource. Due to more livelihood options in Acre, Brazil nuts were relatively less important economically, and were 
Table 5. Mean and standard error of Brazil nut harvest start date (expressed in Julian days where $1=8$ November), quantity of Brazil nuts collected $(\mathrm{kg})$, and harvest duration (days) in three Brazil nut harvest contexts in Bolivia and Brazil in 2006 and 2007.

\begin{tabular}{lccc}
\hline \hline \multicolumn{1}{c}{ Variable } & 1. Bolivia: Thefts & 2. Bolivia: No thefts & 3. Brazil: No thefts \\
\hline Harvest start date & $60.53(1.98)$ & $56.37(2.08)$ & $86.44(2.48) \dagger$ \\
Quantity & $163.12(13.16)$ & $153.53(13.08)$ & $114.34(12.06) \ddagger$ \\
Harvest duration & $94.74(3.66)$ & $91.92(3.83)$ & $43.25(4.43) \dagger$ \\
\hline
\end{tabular}

Notes: Group 3 differed from Groups 1 and 2 for all variables: $\dagger p<0.001 ; \ddagger p<0.01$. Year x group interactions were not significant.

considered just one of many seasonal income and subsistence activities. Although we found only weak statistical evidence that increased income from Brazil nuts was correlated with theft, the relatively high value of this one product in Pando is undeniable. Indeed, when a dramatic rise in global Brazil nut prices occurred in 2005, violent conflicts ensued, which resulted in deaths of several people in Pando (El Deber 2005); no such response occurred in neighboring Acre.

\section{Livelihood, management, and conservation implications}

The difference in threat of Brazil nut theft influenced harvest practices in Acre and Pando. The low incidence of nut thefts in Acre allowed harvesters to be flexible in their collection method. Acrean harvesters typically were unconcerned with potential theft of nuts, and thus began their harvest after most fruits had fallen to the ground. Harvesting later in the fruit-fall season allowed them to concentrate their efforts and collect all nuts within a few weeks. They then transported nuts out of the forest all at once using draft animals, which overall is an easier and more efficient practice. In contrast, harvesters in Pando gathered, opened, and transported nuts from a subset of their trees in one day, and then repeated this process throughout their stand until all trees were visited. They were also compelled to collect nuts early in the season, which is a dangerous and sometimes fatal practice because the heavy fruits are still falling from trees that are up to $50 \mathrm{~m}$ tall. This collection method is also relatively inefficient. Nuts must be carried on the harvesters' shoulders, and then hauled to a storage area or temporary hiding place. During our field research, Bolivian harvesters consistently reported that these procedures diminished the possibility that their gathered fruits could be stolen. Although our data showed no differences in harvest methods between households that did or did not experience thefts, we conclude that the general climate of resource insecurity in Bolivia forced all harvesters to manage their stands as if thefts could occur at any time.

The extended Brazil nut harvest in Pando can also be attributed to rural households' heavy economic dependence on this one product. They need all the cash they can get from their nut stands since there is a distinct lack of economic alternatives in Pando when compared to Acre. Producers in Pando visited the same trees many times over the harvest season to continuously collect fruits immediately after natural fruit fall. Two ecological studies that measured Brazil nut harvest intensity by humans in Acre and Pando support this difference in economic dependence. In Acre, Wadt et al. (2008) reported nut collection intensities of $45 \%$ and $71 \%$ of fallen fruits harvested at two Chico Mendes Extractive 
Fig. 5. Percentage of households using specific Brazil nut harvest methods among three groups: (1) Bolivia with nut thefts, (2) Bolivia without nut thefts, and (3) Brazil without nut thefts. In every case, the proportion of households implementing these methods in Brazil was statistically different from the proportion of households in Bolivia $(p<0.001)$. There were no differences in harvest methods employed by the Bolivian groups (with or without Brazil nut thefts).

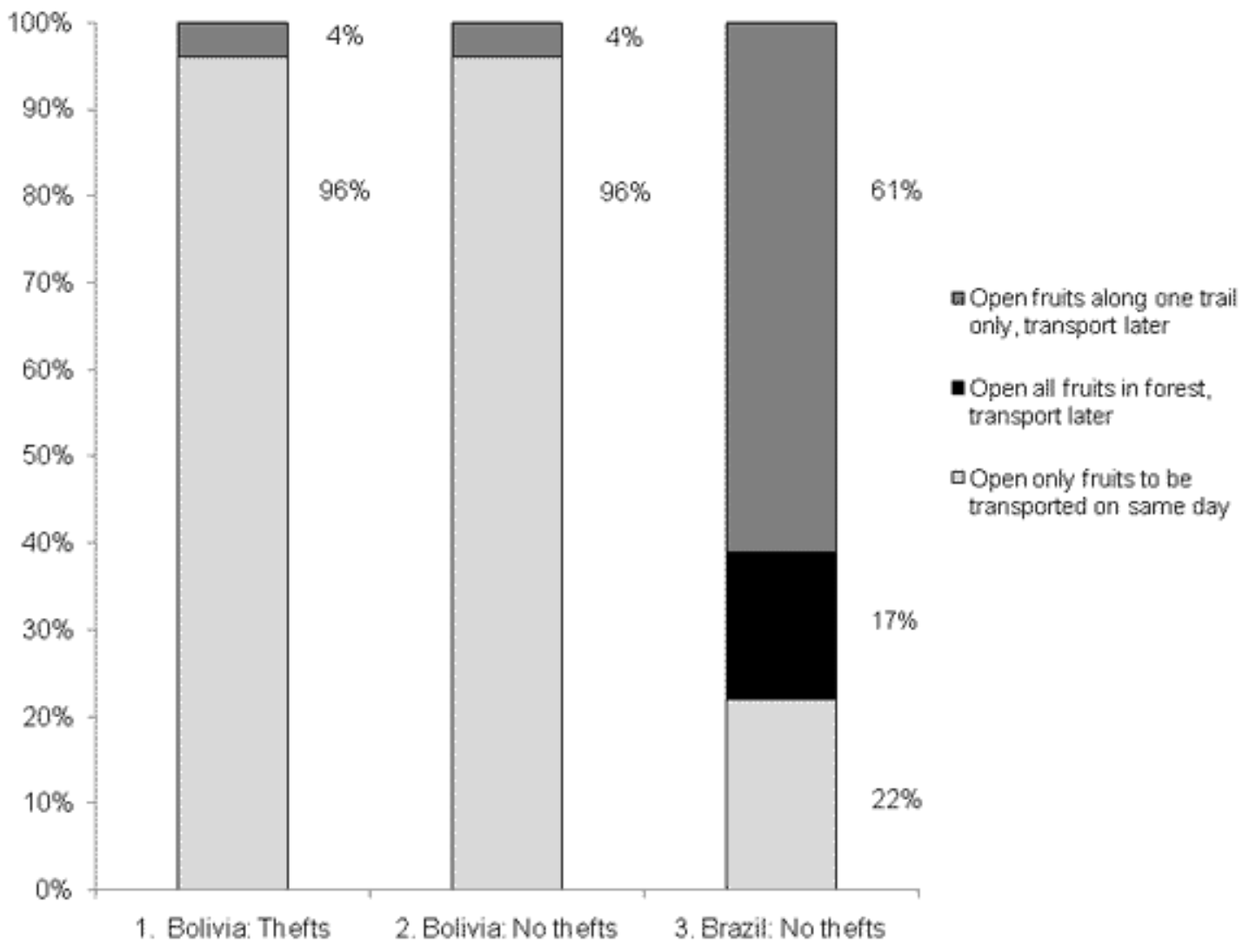

Reserve sites, which is much lower than the estimated $93 \%$ collection intensity reported at sites in Pando by Zuidema and Boot (2002). This economic dependence on Brazil nuts in Pando is likely not only a reason for nut thefts, it also enhances the negative effects of thefts on households that depend on this one product.

These disparate harvest systems in Pando and Acre result in ecological and economic trade-offs. Late season harvests allow Bolivian producers to take advantage of higher nut prices as middlemen and companies attempt to fill their yearly quotas. On the other hand, the Brazilian short-season harvest method may allow a longer period for the scatterhoarding agouti to both consume and disperse nuts, potentially promoting Brazil nut regeneration and long-term ecological sustainability of the system. That said, Brazilian harvesters also commonly convert secondary fallows (which provide favorable regeneration sites for $B$. excelsa [Cotta et al. 2008]) to pasture - a practice clearly detrimental to landscape-level Brazil nut production and forest conservation in general. Nonetheless, cattle production also diversifies the Brazilian livelihood system and results in less dependence on one product.

Finally, different harvest systems in Acre and Pando also have market consequences. A main impediment to international Brazil nut sales is contamination by aflatoxins, which are both toxic 
and carcinogenic, and are produced by the fungus Aspergillus. When European importers raised their quality standards for Brazil nuts in 1998, access to the European market was imperiled (Newing and Harrop 2000). In Acre, fruits that fall in December and are not collected until February or March, appear to have higher aflotoxin risk (L.H.O. Wadt, personal communication) because Aspergillus thrives under hot and humid conditions (Hudler 1998). Nuts transported out of the forest just after fruit fall, as in Bolivia, are less likely to be contaminated. Organic and Fair Trade certification of Brazil nuts, through the sale of an aflatoxin-free product and affiliation with cooperatives, have been important in stabilizing and even increasing the price producers receive for nuts while encouraging better management practices. Interestingly, collection earlier in the season is now being promoted as a "best management practice" in Acre as one step towards attaining certification, which may alter harvest regimes there. That said, given the human safety and ecological concerns associated with early season collection, only one early collection trip after peak fruit fall in January is recommended, especially since the practice of drying nuts postcollection is considered most important for minimizing aflatoxin risk (L.H.O. Wadt, personal communication). If certification were to substantially increase the price for Brazil nuts in Acre, producers might allocate more time to nut collection in relation to other livelihood activities. Nonetheless, while collectors in Acre can flexibly choose nut harvest regime and harvest length, collectors in Pando are forced into an early and lengthy harvest due to threat of theft and high economic dependence on Brazil nuts.

\section{CONCLUSIONS}

Several important lessons can be learned from this comparative study in Western Amazonia. First, the outcome of land tenure reforms depends on the timing and process of property rights formalization in local communities. In Pando, as demand for clear property rights increased with rising prices of Brazil nuts, granting communal titles using a top-down approach sometimes had the unanticipated consequence of enhancing property rights insecurity in any particular community. Bolivian government agencies were unable or unwilling to resolve conflicts over land and resources that arose from competing interests either within communities or between communities and other more powerful actors (Cronkleton et al. 2007). In contrast, in Acre, land conflicts and resource thefts are currently rare among extractive communities. The external Extractive Reserve boundary was strongly enforced and customary internal boundaries were left flexible to accommodate traditional forest use. That said, property rights security does not necessarily translate to forest conservation as producers in Acre exercise their rights to convert small portions of their forested landholdings to pasture. Second, different settlement patterns and market forces appear to have affected nut thefts in forests. In the case of Pando, people are much less connected with their forested landholdings except during the nut harvest. Even though the concentrated settlements have allowed for improved access to government services, this lack of physical connection, combined with a product that is in high demand, may increase the likelihood of conflictive situations. Government support for demarcation of customary landholdings by communities in Pando could be an important way to help strengthen community forest management institutions and mediate conflicts.

The phenomenon of Brazil nut theft has important consequences for rural livelihoods and sustainable forest management. As in other studies on illegal forestry activities, the high incidence of thefts in Pando is clearly detrimental to rural livelihoods (Kaimowitz 2007), primarily through lost forest income and job opportunities but also through threats to physical security. Given the relatively high proportion of rural household income derived from Brazil nuts in Pando, forest-dwelling communities are more vulnerable to the negative effects of a stolen harvest. Additionally, collectors unable to glean sufficient income from nuts are likely to turn to other land uses, which may involve converting Brazil nut-rich forests to agriculture or pasture. Furthermore, the threat of nut theft in Pando locks collectors into a management regime that is clearly dangerous and inefficient, and perhaps detrimental to long-term viability of future Brazil nut tree populations. As trends in designating forests for legal use by local communities continue, it is essential to understand and address the causes and effects of forest-based conflicts to promote rural livelihoods and long-term management and conservation of the world's tropical forests.

Responses to this article can be read online at: http://www.ecologyandsociety.org/vol16/iss 1/art4/responses/ 


\section{Acknowledgments:}

We are grateful to the many Brazil nut harvesters in Western Amazonia who shared their time, information, and lives with us. Juceli Bezerra da Souza, Marciane de Araujo, and Peter Groenendjik offered outstanding field assistance, and EmbrapaAcre, CNPT-IBAMA, Herencia-Pando, and the Reserva Nacional de Vida Silvestre Amazónica Manuripi gave us the necessary institutional support to carry out this work. We thank the editors and three anonymous reviewers for their critiques, along with Francis "Jack" Putz, Marianne Schmink, Brian Child, Grenville Barnes, William Sunderlin, and Peter Frost who provided extremely helpfulfeedback on earlierdrafts of this manuscript. Research funding came from the Rainforest Alliance Kleinhans Fellowship Program, William J. Fulbright Program, Center for International Forestry Research Poverty and Environment Network (CIFOR PEN), and the University of Florida NSF-IGERT "Working Forests in the Tropics" Program.

\section{LITERATURE CITED}

Agrawal, A. 2001. Common property institutions and sustainable governance of resources. World Development 10:1649-1672.

Agrawal, A., and C. Gibson. 1999. Enchantment and disenchantment: the role of community in natural resource conservation. World Development 27:629-649.

Allegretti, M. H. 1989. Reservas extrativistas: uma proposta de desenvolvimento da floresta Amazônica. Pará Desenvolvimento 25:2-29.

Allegretti, M. 1990. Extractive reserves: an alternative for reconciling development and environmental conservation in Amazonia. Pages 252-64 in A. B. Anderson, editor. Alternatives to deforestation: steps toward sustainable use of the Amazon rainforest. Columbia University Press, New York, USA.

Alston, L. J., G. D. Libecap, and B. Mueller. 2000. Land reform policies, the sources of violent conflict, and implications for deforestation in the Brazilian Amazon. Journal of Environmental Economics and Management 39:162-188.

Ankersen, T., and G. Barnes. 2005. Inside the polygon: emerging community tenure systems and forest resource extraction. Pages 156-177 in D. Zarin, F. J. Putz, M. Schmink, and J. Alavalapati, editors. Working forests in the tropics: conservation through sustainable management? Columbia University Press, New York, USA.

Barham, B., and O. Coomes. 1996. Prosperity's promise: the Amazon rubber boom and distorted economic development. Westview Press, Boulder, Colorado, USA.

Belcher, B., M. Ruiz-Perez, and R. Achdiawan. 2005. Global patterns and trends in the use and management of NTFPs: implications for livelihoods and conservation. World Development 33:14351452.

Blate, G. M., F. E. Putz, and J. C. Zweede. 2002. Progress towards RIL adoption in Brazil and Bolivia: driving forces and implementation successes. Pages 217-238 in T. Enters, P. B. Durst, G. B. Applegate, P. C. S. Kho, and G. Man, editors. Proceedings for the International Conference of the Application of Reduced Impact Logging to Advance Sustainable Forest Management. The Asia-Pacific Forestry Commission, Bangkok, Thailand.

Bojanic, A. 2001. Balance is beautiful: assessing sustainable development in the rainforests of the Bolivian Amazon. PROMAB scientific series 4. Riberalta, Beni, Bolivia.

Brown, K., and S. Rosendo. 2000. Environmentalists, rubber tappers and empowerment: the politics and economics of extractive reserves. Development and Change 31:201-227.

Colfer, C. 2005. The equitable forest: diversity, community, and resource management. Resources for the Future Press, Washington, D.C., USA.

Contreras, A., and M. T. Vargas. 2001. Social, environmental and economic dimensions of forest policy reforms in Bolivia. Forest Trends, Center for International Forestry Research, Washington, D.C., USA. 
Cotta, J. N., K. A. Kainer, L. H. O. Wadt, and C. L. Staudhammer. 2008. Shifting cultivation effects on Brazil nut (Bertholletia excelsa) regeneration. Forest Ecology and Management 256:28-35.

Cronkleton, P., M. A. Albornoz, G. Barnes, K. Evans, and W. de Jong. 2010. Social geomatics: participatory forest mapping to mediate resource conflict in the Bolivian Amazon. Human Ecology 38:65-76.

Cronkleton, P., C. Goenner, K. Evans, M. Haug, W. de Jong, and M. A . Albornoz. 2007. Supporting forest communities in times of tenure uncertainty: participatory mapping experiences from Bolivia and Indonesia. RECOFT International Conference: Poverty reduction and forests: tenure, market and policy reforms. Bangkok, Thailand.

Cronkleton, P., and P. Pacheco. 2010. Changing policy trends in the emergence of Bolivia's Brazil nut sector. In S. A. Laird, R. McLain, and R. P. Wynberg, editors. Finding policies that work for non-timber forest products. Earthscan, London, UK.

de Jong, W., S. Ruiz, and M. Becker. 2006. Conflicts and communal forest management in northern Bolivia. Forest Policy and Economics 8:447-457.

Demsetz, H. 1967. Toward a theory of property rights. American Economic Review Papers and Proceedings 57:347-359.

Ehringhaus, C. 2006. Post-victory dilemmas: land use, development, and social movements in Amazonian Extractive Reserves. Dissertation, Yale University, New Haven, Connecticut, USA.

El Deber. 2005. Conflicto por tierras y castaña deja tres muertos. 13 July 2005. Santa Cruz de la Sierra, Bolivia.

Fearnside, P. M. 2003. Conservation policy in Brazilian Amazonia: understanding the dilemmas. World Development 31:757-779.

Fifer, V. J. 1970. The empire builders: a history of the Bolivian rubber boom and the rise of the house of Suárez. Journal of Latin American Studies 2:113146.
Fitzpatrick, D. 2006. Evolution and chaos in property rights systems: the third world tragedy of contested access. The Yale Law Journal 115:9961048.

Fortmann, L., and J. Bruce. 1988. Pages 1-14 in L. Fortmann and J. Bruce, editors. Whose trees? Proprietary dimensions of forestry. Westview Press, Boulder, Colorado, USA.

Gibson, C., E. Ostrom, and M. A. McKean. 2000. Forests, people and governance: some initial theoretical lessons. Pages 227-242 in C. Gibson, M. A. McKean, and E. Ostrom, editors. People and forests: communities, institutions and governance. Massachusetts Institute of Technology, Cambridge, Massachusetts, USA.

Gould, K. 2006. Land regularization on agricultural frontiers: the case of northwestern Petén, Guatemala. Land Use Policy 23:395-407.

Honey Roses, J. 2009. Illegal logging in common property forests. Society and Natural Resources 22:916-930.

Hudler, G. W. 1998. Magical mushrooms, mischievous molds: the remarkable story of the fungus kingdom and its impact on human affairs. Princeton University Press, Princeton, New Jersey, USA.

Kaimowitz, D. 2007. Forest law enforcement and rural livelihoods. Pages 110-138 in L. Tacconi, editor. Illegal logging: law enforcement, livelihoods and the timber trade. Earthscan, London, UK.

Kainer, K. A., L. H. O. Wadt, and C. Staudhammer. 2007. Explaining variation in Brazil nut fruit production. Forest Ecology and Management 250:244-255.

Koning, R., D. Capistrano, Y. Yasmi, and P. Cerutti. 2007. Forest-related conflict: impact, links, and measures to mitigate. Rights and Resources Initiative, Washington, D.C., USA.

Künhe, R. 2004. Conflictos entre uso y protección de los recursos naturales, Reserva Nacional de Vide Silvestre Amazónica Manuripi (RNVSAM). Pages 123-136 in W. De Jong, editor. Retos y perspectivas del nuevo régimen forestal en el norte amazónico 
boliviano. Center for International Forestry Research, Bogor, Indonesia.

Larson, A. M., P. Pacheco, F. Toni, and M. Vallejo. 2007. The effects of decentralization on access to livelihoods assets. Journal of Environmental Development 16:251-268.

Larson, A. M., and F. Soto. 2008. Decentralization of natural resource governance regimes. Annual Review of Environment and Resources 33:213-239.

Marsik, M., F. Stevens, and J. Southworth. In press. Rates and patterns of land cover change and fragmentation in Pando, northern Bolivia from 1986 to 2005. Progress in Physical Geography 35.

McKean, M. A. 2000. Common property: what is it, what is it good for, and what makes it work? Pages 27-55 in C. Gibson, M. A. McKean, and E. Ostrom, editors. People and forests: communities, institutions and governance. Massachusetts Institute of Technology, Boston, Massachusetts, USA.

Meinzen-Dick, R., and E. Mwangi. 2008. Cutting the web of interests: pitfalls of formalizing property rights. Land Use Policy 26:36-43.

Newing, H., and S. Harrop. 2000. European health regulations and Brazil nuts: implications for biodiversity conservation and sustainable rural livelihoods in the Amazon. Journal of International Wildlife Law and Policy 3:109-124.

Ostrom, E. 1990. Governing the commons: the evolution of institutions for collective action. Cambridge University Press, New York, USA.

Ostrom, E. 2003. How types of goods and property rights jointly affect collective action. Journal of Theoretical Politics 15:239-270.

Payne, R. W., D. A. Murray, S. A. Harding, D. B. Baird, and D. M. Soutar. 2007. GenStat for Windows (10th edition) Introduction. VSN International, Hemel Hempstead, UK.

Peres, C. A., C. Baider, P. A. Zuidema, L. H. O. Wadt, K. A. Kainer, D. A. P. Gomes-Silva, R. P. Salomao, L. L. Simoes, E. R. N. Franciosi, F. C. Valverde, R. Gribel, G. H. Shepard, M. Kanashiro, P. Coventry, D. W. Yu, A. R. Watkinson, and R. P.
Freckleton. 2003. Demographic threats to the sustainability of Brazil nut exploitation. Science 302:2112-2114.

Ros-Tonen, M. A., T. V. Andel, C. Morsello, K. Otsuki, S. Rosendo, and I. Scholz. 2008. Forest related partnerships in the Brazilian Amazon: There is more to sustainable forest management than reduced-impact logging. Forest Ecology and Management 256:1482-1497.

Ruiz, S. 2005. Rentismo, conflictos y bisques en el norte amazónico boliviano. Center for International Forestry Research, Bogor, Indonesia.

Sayer, J., J. McNeely, S. Maginnis, I. Boedhihartono, G. Shepard, and B. Fisher. 2008. Local rights and tenure for forests: opportunity or threat for conservation? Rights and Resources Initiative and IUCN, Washington, D.C., USA.

Schmink, M., and C. Wood. 1992. Contested frontiers in Amazonia. Columbia University Press, New York, USA.

Sobrinho, P. V. C. 1992. Capital e trabalho na Amazônia Ocidental. Universidade Federal do Acre, Rio Branco, Brazil.

Souza, C., A. Veríssimo, A. da Silva Costa, R. S. Reis, C. Balieiro, and J. Ribeiro. 2006. Dinâmica do desmatamento no estado do Acre. IMAZON, Belém, Brazil.

SPSS Statistics GradPack 17.0. 2008. Rel. 17.0.0. SPSS Inc., Chicago, Illinois, USA.

Stoian, D. 2000. Shifts in forest production extraction: the post-rubber era in the Bolivian Amazon. International Tree Crops Journal 10:277297.

Sunderlin, W. D., A. Angelsen, B. Belcher, P. Burgers, R. Nasi, L. Santoso, and S. Wunder. 2005. Livelihoods, forests, and conservation in developing countries: an overview. World Development 33:1383-1402.

Sunderlin, W., J. Hatcher, and M. Little. 2008. From exclusion to ownership? Challenges and opportunities in advancing forest tenure reform. Rights and Resources Initiative, Washington, D.C., USA. 
Tacconi, L. 2007a. Decentralization, forests and livelihoods: theory and narrative. Global Environmental Change 17:338-348.

Tacconi, L. 2007b. Illegal logging: law enforcement, livelihoods, and timber trade. Earthscan, London, UK.

Vadjunec, J., C. V. Gomes, and T. Ludewigs. 2009. Land-use/land-cover change among rubber tappers in the Chico Mendes Extractive Reserve, Acre, Brazil. Journal of Land Use Science 4:1-26.

Wadt, L. H. O., K. A. Kainer, C. Cartaxo, G. M. Nunes, F. M. Leite, J. M. Souza, D. A. P GomesSilva, and M. M. Sousa. 2005. Manejo da castanheira (Bertholletia excelsa) para produção de castanha-do-brasil. Documento Técnico Seprof 03. Governo do Estado do Acre, Rio Branco, Brazil.

Wadt, L. H. O., K. A. Kainer, C. L. Staudhammer, and R. O. P. Serrano. 2008. Sustainable forest use in Brazilian extractive reserves: natural regeneration of Brazil nut in exploited populations. Biological Conservation 141:332-346.

Wallace, R. 2004. The effects of wealth and markets on rubber tapper use and knowledge of forest resources in Acre, Brazil. Dissertation, University of Florida, Gainesville, Florida, USA.

Weinstein, B. 1983. The Amazon rubber boom 1850-1920. Stanford University Press, Stanford, California, USA.

White A., and A. Martin. 2002. Who owns the world's forests? Forest tenure and public forests in transition. Forest Trends, Washington, D.C., USA.

Zuidema, P. A. 2003. Ecology and management of the Brazil nut tree (Bertholletia excelsa). PROMAB Scientific Series 6, Riberalta, Bolivia.

Zuidema, P. A., and R. G. A. Boot. 2002. Demography of the Brazil nut tree (Bertholletia excelsa) in the Bolivian Amazon: impact of seed extraction on recruitment and population dynamics. Journal of Tropical Ecology 18:1-31. 